\title{
A literature survey on humidification dehumidification desalination processes
}

\author{
Leila Zili-Ghedira ${ }^{1,}$, Hana Gouider ${ }^{1}$, and Sassi Ben Nasrallah ${ }^{1}$ \\ ${ }^{1}$ Energy and Thermal Systems Laboratory, National Engineering School of Monastir, University of Monastir, \\ Avenue Ibn El Jazzar, 5019 Monastir, Tunisia
}

\begin{abstract}
Potable water scarcity can be considered as a challenge nowadays and at least in the nearest future. Many factors contribute to such situation. Common techniques for desalination purpose include multistage flash, multi-effect distillation and reverse osmosis dedicated essentially to large scales. Humidification Dehumidification Desalination systems appear as low scale installations mainly powered by renewable or geothermal energy. This paper focuses on the state of the art of such installations. It discusses their types, their composition and the available models treating them and their outputs, the plants optimization procedures as well as productivity and costs of these systems. The study aims also the futures of such installations.
\end{abstract}

\section{Introduction}

One of the major problems encountered our days is potable water scarcity: only $0.014 \%$ of available water is usable for human beings [1]. This situation is owed to population increase and water use in different human needs and water developing employ in agriculture and industrial processes. Multiple techniques were developed among centuries to provide fresh water from brackish or sea water. Common ways are multistage flash, multieffect distillation and reverse osmosis, such ones being of great order scales. Among these techniques, the desalination based on humidification dehumidification appears as a low order scale, low energy consumption and easy way of providing fresh water particularly adequate for arid and remote regions and mainly powered by renewable energy. This paper is dedicated to expose the state of the art of such installations. It gives insight on their composition by enumerating the different possible components and the several types of installations encountered. It specifies the different approaches used in literature to study them. It focuses also on the main objectives and outcomes of the available published papers and discusses the different parametric results. It defines the optimization procedures of the plant design, consumption and productivity. It reveals also the cost margins. Finally, it gives ideas on the possible ways of improvement of such installations.

\section{Humidification dehumidification desalination technique}

Desalination technique based on HumidificationDehumidification appears as a promising procedure especially dedicated for small scale production and adapted to remote regions since 1968 [2]. Such technique continues to attract researchers' interest till now. This section is dedicated to understand this system working principle and components, the different varieties encountered and the available approaches used to study them.

\subsection{HDH systems' principle}

The desalination humidification-dehumidification processes are mainly based on the air capacity to carry an appreciable amount of water vapor from contact with hot saline water: $1 \mathrm{~kg}$ of dry air can carry $0.5 \mathrm{~kg}$ of vapor when its temperature increases from $30^{\circ} \mathrm{C}$ to $80^{\circ} \mathrm{C}$ [3]. The process is simple: Sea/Brackish water is preheated by the condensing enthalpy while passing through a condenser. Then a complimentary heat is delivered to the salt water via the use of solar energy, a geothermal heat source or a waste heat. It is that inventiveness which makes such technique so attractive besides using a clean, ecological and free energy. After that, the hot water is spread in an evaporator where it will be in contact with moderately humid air. The air already charged with water vapor consequently crosses the condenser provided with cold salt water. As consequence, the humid air condensates providing the potable water.

\subsection{HDH systems' components}

As advanced previously, HDH installations are based on the use of at least one humidifier and one condenser. The complementary heat accorded to salt water can be available either from the use of solar capture or an exchanger where heat is provided by a geothermal source or a hot waste gas. An air capture can as well be used to heat moving air. A pump is necessary to circulate

\footnotetext{
"Corresponding author: leilazilighedira@yahoo.fr
} 
the water. Air circulation, can be either by natural way or based on the use of a blower.

\subsection{Humidifier}

It is mainly an air/water contact exchanger, generally in counter-current flow way. Typically, the hot salt water is spread on the top of the humidifier downstream and the air circulates upstream either by natural or forced convection. Co-current humidifiers are also possible, but prove lower efficiency. Common humidifiers are composed of multiple parallel plates with sides wetted by water film [4]. Different materials can be employed. Covering plates with cotton or porous tissue is promising in keeping plates always wet. The most efficient humidifiers are those composed of packed beds [5]. Bubble columns represent also a possible technique [5$6]$.

\subsubsection{Condenser}

The most available condensers are those composed of tubing where cold salt water circulates whereas air charged with vapor crosses the condenser. The main problems of that type of condensers are drop in pressure, leakage of saline water and pipes corrosion [7]. Other common types of condensers are flat plane ones [8] and finned-tube ones [9].To overcome the limitations of the usual used condensers, recently, direct contact condensers have been employed proving a much better efficiency [10]. Bubble column condensers were also recently employed [11].

\subsubsection{Captures}

Providing installation, specifically humidifier with hot salt water necessitates the use of a complimentary heating source. This can be achieved using a water capture [12]. The installation performance can be improved and the solar radiation intermittence can be overcome by water storage tank use [13]. Also, some installations are based on air heating via air capture [14]. Productivity of $\mathrm{HDH}$ installations is proven to be better when using water solar capture either than using solar air capture [15]. Integration of PCM in air capture represents a possible improvement way [16]. The used solar water/air captures are commonly flat plate ones with single or double glazing. Including flat external reflectors enhance installations performance [17]. Parabolic trough solar collector can be used as well [18]. Use of solar PV cells to produce electricity for $\mathrm{HDH}$ systems was also investigated [19].

\subsubsection{Pump}

The objective of using pump is circulating salt water over the installation, upwards from condenser bottom to humidifier top. Used pumps are mainly centrifugal ones.
In some cases, in $\mathrm{HDH}$ installations, air circulation is driven naturally. In other cases, this is done by forced flow based on blower use.

\subsubsection{Exchanger}

Especially for cases where complimentary water heat is offered by geothermal source [20] or by heat waste from exhausted gases, a heat exchanger is necessary. Such one can be a tube and shell exchanger one in the first case or a plate one in the second case.

\subsection{HDH system variants}

Multiple HDH systems types are available in literature. One can encounter:

- Open Water - Open Air cycles (Figure 1),

- Open Water - Closed Air cycles (Figure 2),

- Closed Water - Open Air cycles (Figure 3),

- Closed Water - Closed Air cycles (Figure 4).

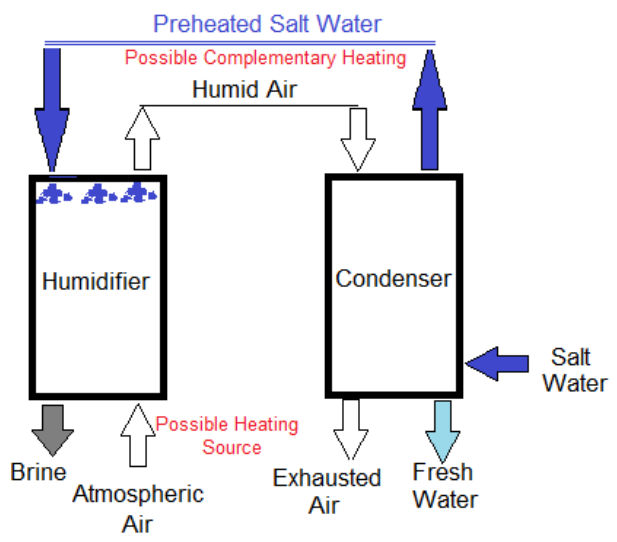

Fig. 1. Open Water - Open Air Cycle.

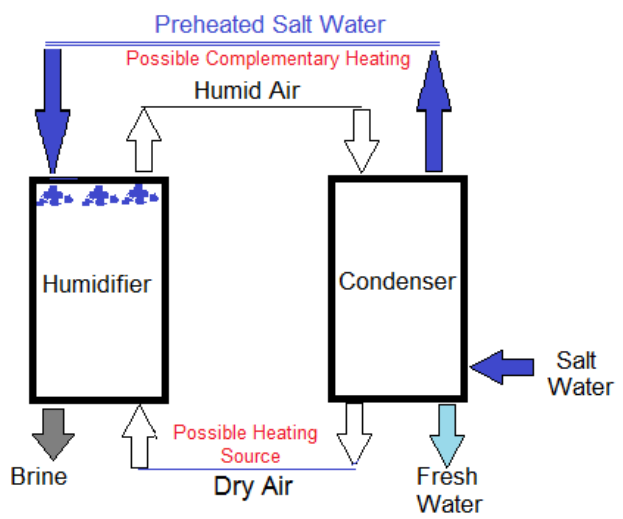

Fig. 2. Open Water - Closed Air Cycle.

\subsubsection{Blower}




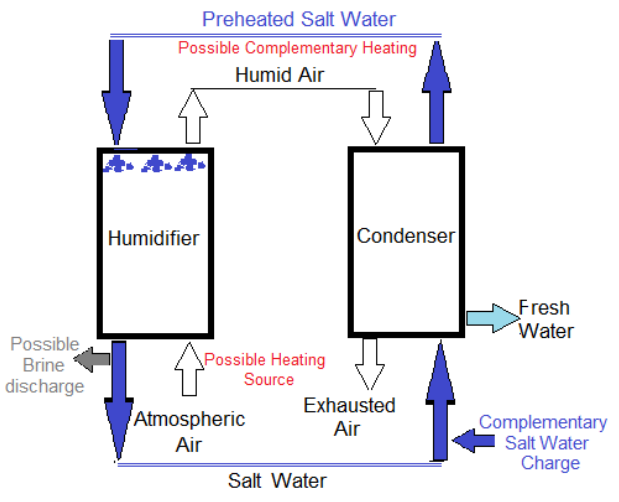

Fig. 3. Closed Water - Open Air Cycle.

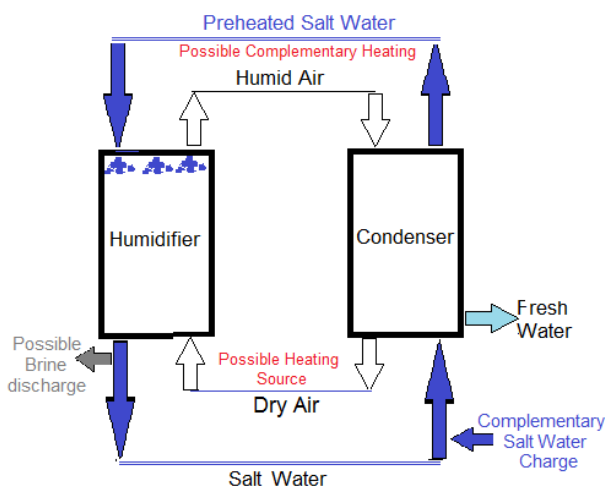

Fig. 4. Closed Water - Closed Air Cycle.

Multi-effect Open Water - Closed Air cycles were been proved to be the most efficient ones among the already cited variants [21]. Also, Open Water - Closed Air water heated HDH have proven their effectiveness [21]. Installations constructed with parietal contact between the humidifier and the condenser are promising regarding heat recovery and installations productivity [22]. Another promising technique is installations with racking from the humidifier/the condenser to the condenser/the humidifier, permitting perfect heat recovery, thermal balancing and entropy generation reduction [23]. HDH installations with double or multiple stages are also encountered and prove better productivity regarding mono-stage installations [24]. The cost evaluation is another criterion that must be explored in detail.

\subsection{HDH systems' studying approaches}

Mainly, HDH systems' studying approaches are either experimental or theoretical. A multitude of experimental $\mathrm{HDH}$ installations are available world wise (China, Jordan, Kuwait, Turkey, ...) either at a laboratory scale, or at an industrial/building scale [25-27]. They aimed mostly evaluating operating parameters effects on installations' productivity. Studies on modified HDH installations are also available [28-29]. The most available numerical studies of HDH systems are based on heat and mass transfer balances for each component of the installation and developing and/or using available heat and mass transfer coefficients [30-32]. The driven numerical simulations aimed studying operating parameters effects as well as geometric parameters and climatic conditions targeting improvement of potable water productivity.

\section{HDH Studies main outcomes}

Essentially, the available HDH installations' studies focus on air and/or water flow rates effects, air and/or water inlet temperatures and dimensions of the different components of the installation (humidifier, condenser, solar capture). The main outcomes of these studies are [21]:

- Productivity is enhanced by increasing salt water temperature at humidifier inlet, air inlet temperature and solar intensity and decreasing cooling water temperature and water flow rate.

- Solar driven HDH installations productivity depends on the season.

- Installations' productivity depends on components dimensions and driven cycle nature (Table 1)

Table 1. HDH installations' productivity [21].

\begin{tabular}{cc}
\hline Type of installation & Productivity \\
\hline Direct contact & \\
Open Water-Closed Air cycle & $12 \mathrm{1} / \mathrm{m}^{2} / \mathrm{d}$ \\
Farid et al. & $6.8-9.8 \mathrm{~kg} / \mathrm{d}$ \\
Nawayesh et al. & $0.65 \mathrm{~kg} / \mathrm{m}^{2} \mathrm{~h}$ \\
Al Hallaj et al. & $6.2 \mathrm{~kg} / \mathrm{m}^{2} / \mathrm{d}$ \\
\hline Direct contact Open Air cycle \\
Dai et al. \\
Direct contact Closed Air cycle \\
Garg et al. \\
Fath et al. \\
Multi stage technique \\
Chafic \\
Multiple effect Closed Air \\
Houcine et al. \\
\hline
\end{tabular}

\section{Optimazation procedures}

Systems efficiency evaluation is essentially based on the following performance parameters [33]:

- Gained-Output-Ratio (GOR): ratio of latent heat of evaporation of produced distillate by total heat input absorbed by solar collector.

- Specific Water Production: amount of water produced per $\mathrm{m}^{2}$ of solar collector area per day.

- Recovery Ratio (RR): ratio of water produced amount per $\mathrm{kg}$ of feed.

- Energy Reuse Factor (f): ratio of energy recovered from heated fluid to energy supplied to heated fluid.

Multiple published papers deal with $\mathrm{HDH}$ installations' optimization. An energy efficient optimization study of HDH installations was conducted by Ashrafizadeh and Amidpour [34]. This study shows 
an 80 to $90 \%$ of total loss related to heater, while no exergy losses related to mass transfers. Mehrgoo and Amidpour proposed a simple approach based on Genetic algorithm methods and Lagrange multiplier methods for optimization purpose [35]. The study shows a best installation performance with inlet heated water temperature increase and cooling water temperature decrease. Hou [36] proceed by applying the pinch technology and makes out that two-stage multi-effect $\mathrm{HDH}$ prove better energy recovery and higher GOR than one stage process.

\section{Economic evaluations of $\mathrm{HDH}$ systems}

Few available papers expose an economic evaluation of $\mathrm{HDH}$ systems. Some of these studies is exposed in table 2 [21].

Table 2. HDH installations' economic evaluation [21].

\begin{tabular}{cc}
\hline Type of installation & Water Production cost \\
\hline Multi stage technique & \\
Chafic & $63.65 \mathrm{USD} / \mathrm{m}^{3}$ \\
\hline Multiple effect Closed Air & \\
Houcine et al. & $53.29 \mathrm{USD} / \mathrm{m}^{3}(18$ stage) \\
& $47.972 \mathrm{USD} / \mathrm{m}^{3}(12 \mathrm{stage})$ \\
& $72.092 \mathrm{USD} / \mathrm{m}^{3}(9$ stage) \\
\hline Solar multi condensation- & \\
evaporation system & $6.58 \mathrm{USD} / \mathrm{m}^{3}$ \\
Yuan et al. & \\
\hline PV powered HDH & \\
Wang et al. & $21.8 \mathrm{USD} / \mathrm{m}^{3}$ (forced air cir.) \\
& $2.3 \mathrm{USD} / \mathrm{m}^{3}$ (free air cir.) \\
\hline
\end{tabular}

One possible future aiming $\mathrm{HDH}$ potable water production cost decrease is its combination with $\mathrm{RO}$ and mechanical compression [37]. A possible way is also thermodynamic balancing and other innovative techniques as mentioned earlier.

\section{Futures}

$\mathrm{HDH}$ installations are attractive procedures used to provide potable water from either brackish or sea water. Their main interesting advantage is that they can be driven using renewable energy, namely solar energy or even waste heat or geothermal resources. Besides, they are practical in remote regions and do not necessitate much technical maintenance. In another hand, they prove to be ecological friendly. Their shortage is the low productivity they achieve and the moderate cost per potable water production. So, the essential challenges to be undergone in the future/possible improving ways of installations are:

- Conducting holistic design improvement approaches which take into account the hole installation performance and not only each component performance as a single part. An attempt in that direction is available [38].

- Considering and evaluating the combined effects of all the involved parameters: water/air flow rates (their ratio), water/air inlet temperatures, contact surfaces in humidifier/condenser, co-current/countercurrent exchangers, collectors surfaces, ...

- Comparing different possible configurations of $\mathrm{HDH}$ systems when conducted with involved parameters and geometric considerations (possible cycles with natural/forced circulation of water/air, double/multistage installations, installations with Humidifier/condenser wall contact, installations with racking ...).

- Conducting research studies detailing all performance parameters, including representative installation cost evaluation and potable water production cost, ...

- Proposing solutions for solar energy intermittence and ways to overcome its effect on installations' ability to work throughout the whole day which affect seriously the installations production. A study focusing on remediating to such constraint is available in literature [39]. Use of nanoparticles for solar collectors' fluids shows enhancement in thermal efficiency of solar captures [40].

- Developing new combinations between HDH systems and other technologies, mainly RO and thermal $\mathrm{VC}$ to be competitive at large scale.

\section{References}

1. J. Bendfeld, Ch. Broker, K. Menne, E. Ortjohann, L. Temme, J. Vob, and P. C. M. Carvallo, Proceedings of $2^{\text {nd }}$ World Conference and Exhibition on Photovoltaic Solar Energy Conversion, Vienna, 6-10 July, (1998).

2. I.S. Bourouni, M.T. Chaibib, and L. Tadrist, Desalination, 137, (2001).

3. S. Parekh, M.M. Farid, J.R. Selman, and S. AlHallaj, Desalination, 160, (2004).

4. M.A. Kassim, B. Benhamou, and S. Harmand, Appl. Therm. Eng., 31, (2011).

5. R.E. Treybal, Mass Transfer Operations, NewYork, USA, McGraw-Hill(1980).

6. L. Zhang, W. Chen, and H. Zhang, Desalination and Water Treatment, 51, (2013).

7. N. Niroomand, M. Zamen, and M. Amidpour, Desalination and Water Treatment, 54, (2014).

8. M. Sievers, and J.H. Lienhard, Heat Transfers Eng., 34, (2013).

9. S.A. El-Agouz, and M. Abugderah, Energy Conversion \& Management, 49, (2008).

10. J.F. Klausner, Y. Li, and R. Mei, Heat Mass Transfer, 42, (2005).

11. E.W. Tow, and J.H. Lienhard, Int. J. Thermal Sciences, 80, (2014).

12. A.M. Abdel Dayem, J. Solar Energy Eng., 136, (2014). 
13. J. Moumouh, M. Tahiri, and M. Salouhi, Int. J. Hydrog. Energy, 39, (2014).

14. A.E. Kabeel, and E.M.S. El-Said, Desalination, 341, (2014).

15. C. Yildirim, and I. Solmus, Energy Conversion \& Management, 86, (2014).

16. E.K. Summers, M.A. Antar, and J.H. Lienhard, Solar Energy, 86, (2012).

17. N.A.S. Elminshawy, F.R. Siddiqui, and M.F. Addas, Desalination, 365, (2015).

18. A.M.I. Mohamed, and N.A. El-Minshawy, Energy Conversion \& Management, 52, (2011).

19. A. Giwa, H. Fath, and S.W. Hasan, Desalination, 377, (2016).

20. A.M.I. Mohamed, and N.A.S. El-Minshawy, Desalination, 249, (2009).

21. H. Sharon, and K. S. Reddy, Ren. and sust. energy reviews, 41, (2015).

22. B.M. Hamieh, and J.R. Beckman, Desalination, 195, (2006).

23. K.M. Chehayeb, G. Prakash Narayan, S.M. Zubair, and J.H. Lienhard, Int. J. Heat Mass Transfers, 68, (2014).

24. K.M. Chehayeb, G.P. Narayan, S.M. Zubair, and J.H. Lienhard, Desalination, 369, (2015).

25. Y. J. Dai, and H. F. Zhang, Desalination, 130, (2000).

26. S. Al-Hallaj, M. M. Farid, and A. R. Tamimi, Desalination, 120, (1998).

27. G. Al-Enezi, H. Ettouney, and N. Fawzy, Energy conversion \& management, 47, (2006).

28. R. H. Xiong, S. C. Wang, L. X. Xie, Z. Wang, and P. L. Li, Desalination, 180, (2005).

29. S. A. El-Agouz, Energy, 35, (2010).

30. J. Orfi, N. Galanis, and M. Laplante, Desalination, 203, (2007).

31. A. Eslamimanesh, and M.S. Hatamipour, Desalination, 237, (2009).

32. R. Xiong, S. Wang, and Z Wang, Desalination, 196, (2006).

33. G. Prakash Narayan, M. H. Sharqawy E. K. Summers, J. H. Lienhard, S. M. Zubair, and M.A. Antar, Ren. and Sust. Energy Reviews, 14, (2010).

34. S. A. Ashrafizadeh, and M. Amidpor, Desalination, 285, (2012).

35. M. Mehrgoo, and M. Amidpour, Desalination, 293, (2012).

36. S. Hou, Desalination, 222, (2008).

37. A. Giwa, N. Akther, Al A. Housani, S. Haris, and S. W. Hasan, Renew. and Sust. Energy Reviews, 57, (2016).

38. A.E. Kabeel, M.H. Hamed, Z.M. Omara, and S.W. Sharshir, Energy, 68, (2014).

39. G. Yuan, and H. Zhang, Desalination, 205, (2007).

40. H. Mokhtari, H. Ahmadisedigh, and I. Ebrahimi, Desalination, 377, (2016). 